\title{
Chapter 9. Houses and the Built Environment in Island South-East Asia: Tracing some shared themes in the uses of space
}

\section{Roxana Waterson}

The place of architecture in people's lives is a subject which anthropologists have, to a surprising degree, been guilty of neglecting. The extent of this neglect was highlighted recently by Caroline Humphrey (1988) in a review of Paul Oliver's (1987) Dwellings: the house across the world. Oliver is one writer who has consistently and creatively crossed the boundary between architecture and anthropology, and his work should inspire greater efforts to make good the many areas of neglect still existing in the anthropology of architecture. The Austronesian world provides one of the richest fields for enquiry into this topic, and one which promises to yield new insights into other aspects of social life and organization.

Architectural styles can change rapidly — but they can also maintain continuity over surprisingly long periods. The antiquity of some aspects of architectural style in the Austronesian world is undoubted. Elements such as pile building and the saddle roof with its extended ridge line are first to be seen on the bronze drums of the Dong Son era, but to judge from their appearance in regions as distant from the mainland as Micronesia and New Guinea, it is reasonable to assume that they are much older than their earliest surviving pictorial representations: in other words, that this style is a genuinely Austronesian invention. What is intriguing about the pursuit of meaning in Austronesian built form, however, is what it reveals to us about the continual recurrence and re-use, not just of material forms but of more abstract themes and ideas. ${ }^{1}$ Such themes mould the way that people live in the buildings they create and their relations to each other. Ultimately they concern ideas as fundamental as the nature of life processes themselves. This paper attempts to summarize briefly some of these themes, as I have come to perceive them over five years of research into the vernacular building traditions of South-East Asia; a fuller treatment of them is to be found in Waterson (1990).

\section{Structures and Functions}

Dutch visitors to Indonesia often recorded disparaging impressions of the buildings they saw. Not only did these buildings strike an unfamiliar note aesthetically since they often lacked walls and windows, being dominated instead 
by roof, but in addition their interiors were perceived as dark, smoky, overcrowded, dirty and insect-ridden. It was rarely noted that the inhabitants spent little time in these buildings during the day; the principle function of the house being as the origin-site, and storage-place for heirlooms, of a group of kin. In fact, a number of structures in the island South-East Asian world have been designed to complement the enclosed form of the house itself and provide shady open spaces for daytime use: from the tagakal-roofed platforms of the Yami of Lanyü Island, through the pavilions of the Balinese house courtyard, to the platform underneath the granaries of the Toraja of Sulawesi and the Ema of Timor. Understanding built form thus requires, among other things, a consideration of the relations between different types of structure and the distribution of functions between them. In addition, we need to study the motivations behind the buildings, which in island South-East Asia would appear to have a great deal to do with the interweaving of kinship structure, rank and ritual.

The function of the house as dwelling is relatively insignificant in some of these societies. One finds numerous examples, from Madagascar to Timor, of houses or origin-villages left empty save for important ritual occasions. It is their importance as origin-places which causes those who trace ties to them to spend sometimes large amounts of money on their upkeep, and to return to them from great distances for the celebration of rites. Occasionally, as among the Merina of Madagascar (Bloch 1971:131) or the Nuaulu of Seram, houses are continually in process of construction, but rarely ever finished. For the Nuaulu, says Ellen (1986), 'there is a notion of an ideal house which is only temporarily realized, but which people are always striving toward' (p.26). For the Toraja, rebuilding is the process which transforms an ordinary dwelling into an origin-house, and the more times it is repeated, the greater the house becomes. It is because of this fusing of habitation and ritual site that some houses come to have the nature of temples, and to be referred to as such in the literature. In most of the indigenous religions of the region, we find an absence of permanent buildings set aside for sacred purposes, but the house itself is charged with the power of the ancestors and of the sacred heirlooms stored within it. Granaries too may serve sacred as well as practical functions, for rice is typically treated with great deference. House, granary and sacred site may even be fused into a single structure, as among the Ifugao, Donggo or Alorese.

The same ambiguity or fusing of functions pertains to 'public' buildings. Such structures, again, are absent in many South-East Asian societies. Borneo longhouses combine public and private spaces within a single structure; among the Toraja, the platforms of privately owned rice barns are utilized for public functions, as sitting-places for guests at ceremonies or for elders hearing a village dispute. Structures called bale, or variants thereof, though extremely widespread throughout the archipelago, are by no means uniform in their appearance and 
function. Two predominant meanings of the word appear to be 'an unwalled building' and 'a meeting-hall', but in some instances bale refers to a dwelling, and the range of referents which has developed in eastern Austronesia is very wide. Certainly it seems illegitimate to generalize, as Rassers (1959) did, that 'public' buildings are 'men's houses'; this is actually a rare institution in Indonesia. Where public buildings do exist, their use may articulate a distinction not simply between men and women but between the married and the unmarried. Most communal structures are used as sleeping-places for unmarried males, and one can find one or two unusual instances of structures built especially for unmarried girls or boys. On Siberut, according to Kis-Jovak (1980:26), Sakuddei boys sometimes build themselves a special house in adolescence, while Loeb (1935:56) reported the existence of communal girls' houses among the 'southern Batak', where girls spent the night with an older woman as chaperone, and were allowed to receive their suitors for conversation and an exchange of betel-nut. The kusali of Tanimbar is a curious instance (which may have existed only in myth) of a structure in which a very high-ranking girl might be secluded, surrounded by 'female' valuables, for a period before her marriage (McKinnon 1983:28).

Houses, then, rather than public buildings, must be viewed as the dominant structures in the organization of the community. In many instances there is something of a continuum between 'public' and 'private' buildings, 'temple' and 'house', while the significance of dimensions such as sacred/profane, male/female and married/unmarried requires critical examination in each instance. Rather than a too hasty categorizing of structures themselves, a close consideration of the distribution of functions proves a better way of understanding the interrelation of built forms.

\section{The House as an Animate Entity}

The house commonly forms a microcosm; its layout and decoration reflecting images of society and cosmos. Attitudes toward houses themselves are an integral part of peoples' world-views and need to be understood in this wider context. A fundamental feature of the indigenous 'animist' religions of South-East Asia is the belief that the universe is suffused with a vital force which may attach itself in differing concentrations to people and things. Humans thus participate in the cosmos on much the same terms as everything else; this results in a particular attitude towards the world, in which objects as well as some quite abstract categories can be considered as subjective entities with whom communication is possible (Endicott 1970; Benjamin 1979). Frequently, though not invariably, this vital force or some aspect of it, is known by the term semangat or its cognates. These ideas are elaborated to greater or lesser degrees through the archipelago, and without wishing to over-systematize their variety, it is impossible to ignore the frequency with which ethnographers record ideas that 
the house itself has a 'soul' or vital force: Malay, semangat rumah; Buginese, sumange' or pangngonroang bola (a house's vital force or 'spirit warden'); Sakuddei, simagere; Savunese, hemanga; and Atoni, smanaf, provide a few notable examples (Endicott 1970:51; Errington 1983; Pelras 1975; Schefold 1982; Kana 1980:229, n.7; Schulte Nordholt 1971:137-138).

Howe (1983) writes of Bali that 'all buildings are considered to be "alive"', a fact 'whose omission from the literature is quite remarkable' (p.139). In what exact sense buildings are regarded as alive is not easy to describe. A number of elements may be involved in the process by which life is thought to enter a building: the conversion of forest trees (which have their own vital force) into timbers, the construction process itself, the carving or decoration of the timbers and, perhaps most significantly, the rituals carried out during house building. Moreover, the elaboration of body symbolism and anthropomorphic (or zoomorphic) imagery in speaking about the house is so detailed and explicit in many cases as to reinforce strongly the idea of the house as a 'living' thing (see, for example, Howe 1983:149 on Bali; Forth 1981:29 on Sumba; Hicks 1976:56-66 on the Tetum of Timor). Finally, rituals held to deal with the destruction or 'death' of a house may vividly highlight the fact that it is viewed as an animate entity. In my own fieldwork in Tana Toraja I had occasion to witness such rites performed after a fire destroyed most of a village along with two old noble origin-houses or tongkonan. Some villagers described the rites as a 'funeral' for the 'dead' houses; the small buffalo sacrificed on this occasion being intended, they said, to accompany the soul of the oldest origin-house to the afterlife. Others stressed that an origin-house should never disappear, and viewed the rites rather as a means of declaring the continuing existence of the houses until such time as they could be given physical form once again through rebuilding.

\section{Houses as Units of Kinship}

This leads to the observation that a 'house', in South-East Asia, constitutes not just a physical structure but also the group of people who claim membership in it. Fox (1980), for example, has noted in the eastern Indonesian context that 'house' is one of the most fundamental and salient categories used by people in talking about social groupings, though it is 'remarkably flexible in its range of applications' (p.12). The relation between houses and kinship groupings, and the manner in which people trace their ties to and through houses, I believe, provides us with the real key to the understanding of the house in South-East Asian societies. At the same time it proffers the chance of advancing our understanding of kinship systems which themselves have never fitted comfortably into more conventional anthropological categories. Lévi-Strauss' (1983) fertile concept of 'house societies' provides a useful and thought-provoking starting point for examining this question. However, the vagueness of his formulations in some crucial respects means that their application is still a matter 
for testing and debate (see, for example, the essays in Macdonald 1987). It is unclear, for example, how many of the wide range of Borneo or Philippine societies, which include both very egalitarian and strongly hierarchical groups, may usefully be defined as 'house societies', or whether it is only the hierarchical ones which exhibit all the features which Lévi-Strauss defines as characteristic of the phenomenon. Again, where longhouse arrangements are concerned, there is some ambiguity about whether the 'house' as a unit should be deemed to consist of the whole longhouse, or the apartments which make it up. The characteristics of the 'house', as Lévi-Strauss describes them, may in some instances be split between the two (Sellato 1987; Guerreiro 1987). Further testing of Lévi-Strauss' concept in the societies of island South-East Asia promises to provide some fresh understandings of the kinship systems of the region.

\section{Social Relationships and the Uses of Space}

How do people order their daily activities and interactions within the built forms that they have created? Rules about the uses of space oblige people to act out their relationships to each other in a particularly immediate and personal way, and they provide one of the most important means by which the built environment is imbued with meaning. Bourdieu (1977:90) describes the house as a 'book' which children learn to read with the body, and from which they learn their vision of the world. This 'em-bodying of the structures of the world' becomes a powerful tool for the reproduction of culture precisely because the principles thus transmitted in condensed, symbolic form are simultaneously placed beyond the grasp of consciousness (Bourdieu 1977:94). They thus remain unchallengeable. But where in Berber society, as Bourdieu describes it, the symbolic system revolves around the all important division between male and female, 'public' and 'domestic', South-East Asian views of the world typically begin from different premises. Here, as Errington (1984) has expressed it, 'the system of gender may include notions of a difference, but it is not the difference that makes a difference, the fundamental difference on which other differences are predicated' (p.2). On the contrary, other dimensions of organization, such as rank, may cut right across gender divisions. Most societies of western Indonesia appear to pay remarkably little symbolic attention to distinctions of gender; in eastern Indonesian societies, where they are highly elaborated, the predominant theme is not separation and opposition, but rather the complementarity of male and female and their bringing together in fertile fusion.

A second possible dimension of spatial and social arrangements which demands particularly careful scrutiny in the South-East Asian context is that between the 'public' and the 'domestic'. This division, and the attempt to relegate women to the 'domestic' world, has frequently been identified as a prominent feature of the development of industrial capitalist economies during the last century. Within this economy, production and paid labour take place outside 
the household, which becomes the locus merely of consumption and of the unpaid labour of women in reproducing the workforce. Power, whether economic, political or religious, resides outside the domestic domain, so that the latter inevitably becomes identified as the place where power is not. Those confined to the domestic domain thus find themselves trapped in a dependent and marginalized position, cut off from 'cultural' activity in general and at risk even of being regarded as less than complete persons.

The sphere of the 'domestic', by contrast, is closely associated with the function of reproduction, which is deemed to be 'natural' to women. Ortner (1974) and others have argued that this structure of ideas can be used more universally to explain the subordination of women cross-culturally. But since they really derive from a Western framework of ideas, we cannot uncritically assume that they will apply in other cultures too. In response to Ortner, a number of anthropologists have been prompted to develop much closer analyses of the variable patterns linking male and female, nature and culture, and the public and domestic spheres in different societies. It has consequently been demonstrated that the content of all these oppositions (where they can be said to exist at all) may in fact fail quite markedly to coincide with our own (Tiffany 1978; Weiner 1978; MacCormack and Strathern 1980; Strathern 1984). The 'domestic' is a culturally relative concept, and in other societies, even where it exists as a category, we cannot simply assume that the political, ritual or economic action is taking place elsewhere. Tiffany (1978), for example, notes the lack of consensus in anthropology over what constitutes 'politics', and particularly the tendency to dismiss or overlook informal processes. Weiner (1978) argues that for the matrilineal Trobrianders, women's reproductive powers are not merely 'natural' but cultural; through childbirth (and their roles in ceremonies and wealth exchanges) they ensure the continuity of the matrilineal kin group or dala, and thus perpetuate social groups and identities (p.175). And La Fontaine (1981) reminds us that the domestic group, far from being the irreducible 'building block' of society, is itself the product of wider social relations. Its isolation is only apparent, for its very existence is predicated upon the existence of other similar units.

In non-industrial economies, the economic demands placed upon the household usually involve production for wider ends than mere subsistence: bridewealth, feasting or prestations of different kinds. She concludes that: 'The division into domestic and public which is made in some, but not all, societies is not a description of structural cleavages but a symbolic statement whose meaning we must interpret in each instance where we find it' (La Fontaine 1981:346).

In the South-East Asian world, too, the concept of domesticity would appear to be of limited relevance in explaining the meanings associated with the house 
and its space. Firstly, the economy itself is typically organized around the household as the basic unit of production as well as consumption, with women playing substantial roles in agriculture and the control of household produce. Given the importance of house units in traditional kinship and ritual systems, as well as political processes, it would be unwise to regard the house as being 'outside' any of these spheres. Frequently, too, as among the Northern Thai, Acehnese, Minangkabau or Toraja, rather than woman belonging to the home, it is the home which belongs to her. In examining uses of space and their symbolic implications, then, it is essential to avoid any preformed conclusions about the hierarchical implications of associations with gender. The kitchen or hearth, for example, although closely associated with women in their nurturing capacities, was often centrally located (as in older Toraja houses). Rather than a division between 'back' and 'front' portions of the house, in a number of cases the more meaningful contrast would appear to be between 'inner' and 'outer' parts, women often being associated with the womb-like 'inner' portion of the house - the source of life, fertility and nourishment.

One type of rule about the uses of space which serves particularly clearly to define social relationships is that which prohibits particular individuals from entering a certain space. This imposes on them a kind of vigilance about their own movements and forces them to be aware of the status distinction embodied by the rule. In the asymmetric alliance systems of eastern Indonesia we can find a number of examples where in-marrying women are excluded from certain areas of the house. For example, among the Atoni of western Timor a wife, as an in-marrying affine, has access to the inner section of her husband's parents' house only after she has been initiated into his descent group ritual (Cunningham 1964:39). This temporary restriction thus marks the process of her acceptance by the husband's kin group (though in practice a considerable proportion of Atoni marriages are uxorilocal). Cunningham describes the use of the inner (or back) section of the house principally by women and the outer (or front) by men as being co-ordinate with Atoni ideas of subordination and superordination respectively. But he goes on to draw a comparison with traditional political arrangements, and it is precisely at this point that we encounter Atoni ideas of sacredness and the 'still centre' of the kingdom, a palace where a sacral ruler, actually a man but characterized as 'female' (feto), ideally should remain motionless. The rest of the kingdom was divided into four 'great quarters', each headed by a secular lord called monef-atonif ('male-man'). (Note the symbolic relativity of gender here.) It becomes a nice point whether it is the periphery or the centre which should be considered superior. In some contexts, the 'inner', left or 'female' section of the house is treated as if it were subordinate. Yet it is the left which is most closely associated with ritual, in which the 'female', and women themselves, play a pivotal role. They, after all, form the mediating category between wife-givers and wife-takers. Furthermore Cunningham 
(1964:60) states that ritual or spiritual matters, far from being associated with a 'subordinate' sphere, are actually considered superior to secular affairs.

Among the Ema of Central Timor, studied by Clamagirand (1975), the house floor is divided into two unequal parts, a 'male' and 'female' side, called the 'great' and 'small' platforms. The great platform is used for the storage of heirlooms and the performance of rituals. In earlier times, an in-marrying woman, for whom bridewealth payments and counter-exchanges had not been completed, was not allowed to set foot on the great platform. A very similar division of floor space, with the same restriction on women for whom bridewealth payments had not been completed, exists among the inhabitants of Rindi in eastern Sumba (Forth 1981:38), while in Tanimbar it is the bride's home village, rather than a part of the spouse's house, which becomes temporarily off-limits to her. This is the case, according to McKinnon (1983:250), where a high-ranking woman is married in an alliance which aims to repeat an already-established affinal link with another high-ranking house. She then cannot return to her village at just any time, but must wait until her husband and the wife-taking group of his house are ready to make another major prestation to their wife-givers.

In all these cases we are dealing with alliance systems which tend to conceptualize marriage in terms of the transfer of women between houses. In all of them, kinship ideology tends toward the patrilineal, even though actual marriage and residence patterns may be highly flexible. Not surprisingly, this kind of spatial rule is unlikely to occur in societies with bilateral kinship systems, such as the Toraja. Here, house membership for the individual is much less exclusive, and the apparent contradiction posed by the arrival of a new member presents less of a conceptual problem. What, however, of peoples like the Acehnese, whose kinship systems show distinct matrilineal bias combined with rules of uxorilocal residence? Might such rules occur in inverse form where it is men who are the newcomers in their wives' houses? (See paper by Cecilia $\mathrm{Ng}$ in this volume.)

An interesting analysis by Dall (1982) of the uses of space within the Acehnese house suggests the need for caution in making any assumption about the 'inferiority' of rear parts of the house, which are particularly the domain of women. In some ways these are better seen as 'inner', in relation to the front part of the house, used by men, which is 'outer'. Alternatively, one can view the central bedroom as the most important and 'inmost' part of the house, in relation to which both male and female ends are 'outer'. It is in the bedroom, where procreation takes place, that the uniting of male and female principles is symbolically represented by the two main posts, called 'prince' and 'princess', against which the bridegroom and bride are seated on their wedding day. Dall (1982) states that his male informants regarded the carved and decorated front balcony as the most important part of the house. He apparently was not in a 
position to collect female informants' views of their homes, but given that women are actually the house owners, he cannot avoid wondering whether the decoration is not perhaps intended to 'keep the guests happy'. He echoes the impressions of previous writers, such as Snouck Hurgronje (1906) and Siegel (1969:55), that the house remains essentially the domain of the woman, and that the man, in spite of the respect accorded to him while at home, remains little more than a guest (Dall 1982:53). The same pattern is, if anything, even more pronounced among the Minangkabau, where the position of an in-marrying son-in-law is notoriously tenuous. And a final, striking example comes from the Rejang, as described by Jaspan (1964), where in ssemendo marriages (involving bride service and a much reduced bridewealth payment), the uxorilocally residing husband was confined like a guest to the veranda and the front room. Putting all these examples together, what we see is not a simple division between 'male' and 'female' spaces, or between 'front' and 'back' as superior/inferior, but the expression of a relation between affines, involving the gradual incorporation of an in-marrying member into the house. In the latter instances, rather than women being 'confined' to the back of the house, it is men who are 'confined' to the front - a dubious honour at best.

In a number of other cases, such as Sunda (Wessing 1978) and south central Java (Tjahjono 1988), 'inner' parts of the house are used for the storage of rice, which itself is intimately associated with women - as evidenced in its widespread personification as a goddess (Dewi Sri in Java and Bali, Lady Koosok in Thailand, and other variants in different parts of the island South-East Asian world). Frequently, whether granaries are separate structures or incorporated into the house, it is the woman who has sole access to the rice store (see, for example, Wessing 1978:55 on Sunda; Hitchcock 1986:26 on the Dou Wawo of Sumbawa; and Barnes 1974:76 on Kedang). In Tana Toraja, too, though men are not prohibited from entering the granary, it is women who customarily control the rice store and remove rice for daily consumption. In Savu, where we again find a marked division of the house into a 'male' and a 'female' side, it is the enclosed and 'female' side which is the place of storage (and cooking) of grain (Kana 1980). The Savu house, like so many houses of the archipelago, is windowless, dominated by its enormous roof. Its enclosed part is symbolically womb-like, in Kana's words, 'dark, female and hidden'. The profound symbolic tie between women and grain in all these cases is a reflection not just of the important economic and productive roles played by women but of a deeper association between agricultural and female fertility, between the nurturing capacities of women as child-bearers and as farmers. Respect for this creative power is echoed in the spatial rules surrounding the rice store. 


\section{Trunk and Tip, Centre and Periphery: Images of Growth and Power}

A recurring chain of associations appears to exist in many Indonesian societies between the idea of centres, navels, and root/trunk ends of plants, forming a complex of ideas, which resonate with deep significance throughout the archipelago. Given their widespread occurrence and the fact that the origins of some of the key terms involved are Austronesian, it appears to be a strong possibility that this is a distinctively Austronesian set of ideas. Centres, navels and roots are all metaphoric sources of vitality; the botanic metaphors of 'trunk' and 'tip' occur not just in rules about the correct 'planting' of house posts but as ways of talking about kinship, for example: women, wife-givers, or senior houses are all in particular Indonesian societies contrasted with men, wife-takers, or junior houses, as 'trunk' to 'tip' (see for example Forth 1981:201 on Sumba; Lewis 1983:36 on the Ata Tana Ai of Flores; and Schulte Nordholt 1980:241 on the Atoni). Immobility and fertility seem frequently to be associated with the centre; the idea of rulers or ritual specialists 'staying put', often actually in a house, recurs with noticeable regularity. Immobility, again, is a prominent feature in wedding ceremonies (as among the Malays, Bugis and Minangkabau) at which the bride and groom, dressed as 'king' and 'queen' for the day, must sit motionless for hours at a time. Immobility thus is utilized as a way of representing a concentration of creative, supernatural or political power.

Since in some cases there appears to be a clear association between 'male' mobility and 'female' immobility, it might be tempting to equate the former with independence, freedom and power, and the latter with dependence and confinement. But I would argue that here especially interpretative caution is required. For, as we see, immobility is frequently used in a ritual context to signal high status and concentration of power. Moreover, whether the 'still centre' is identified as male or female may in fact vary according to context. In any case, symbolic oppositions such as these do not necessarily translate into any literal confinement of women within the house such as Bourdieu describes for the Berber. On the contrary, women play active roles in economic, ritual and, at times, political life.

That this immobility is in fact frequently matched symbolically with the female principle, and the idea of the mother as source, is nowhere more dramatically demonstrated than among the Tetum of Timor, described by Hicks (1976:31). Here, the house is conceptualized as a body, the main room being called the 'house womb'. This is the centre both of domestic and ritual activity, containing the hearth and the ritual ancestral pillar. Here, a woman gives birth, aided by a midwife who, after delivering the baby, fastens a pouch containing the afterbirth to the ritual pillar, and drops the soiled birth cloths onto the ancestral altar. This act (which would be an unthinkable desecration in any 
culture where the categories of 'male' and 'female' are polarized as 'sacred' and 'profane') perhaps demonstrates more dramatically than any other example the extremely positive associations of female reproductive powers in the South-East Asian world.

It is in this light that we must view the recurrence of the idea of the house as womb, implicit in some cases but quite explicit in others. What difference is there, if any, between the womb-house of the Tetum or the Savunese and that of the Berber as described by Bourdieu? Are we faced here simply with a form of universal symbolism, so fundamental that it will tend to present itself to house dwellers anywhere in the world? I would argue that this is not the case, for it is by very different routes that peoples may arrive at such equations. In a patriarchal society, the dependence upon women for the furtherance of life may come to seem an uncomfortable anomaly. Rather than celebrating biological life processes as being the very stuff of religion, these are associated instead with sin, corruption and mortality. In the world religions they are viewed as intrinsically opposed to the life of the spirit, to which men claim privileged access. But in the house-based societies of Indonesia, instead of a realm of the 'sacred' being sharply defined in opposition to the 'profane' world, there is rather a sort of continuity of sacredness, which makes sense in terms of the monistic world view, in which everything in the cosmos is imbued with vital force. Thus the fact of the womb as life-source serves here only as the starting-point for a wide-reaching web of ideas about life processes and the reproduction of social groupings, which themselves are intimately identified with the house.

\section{References}

Barnes, R.H.

1974 Kédang: a study of the collective thought of an eastern Indonesian people. Oxford: Clarendon.

1977 Mata in Austronesia. Oceania 47(4):300-319.

Benjamin, Geoffrey

1979 Indigenous religious systems of the Malay peninsula. In A.L. Becker and Aram A. Yengoyan (eds) The imagination of reality: essays in Southeast Asian coherence systems, pp.9-27. Norwood, NJ: Ablex.

Bloch, Maurice

1971 Placing the dead: tombs, ancestral villages, and kinship organization in Madagascar. London: Seminar Press.

Bourdieu, Pierre 
Inside Austronesian Houses

1977 Outline of a theory of practice (translated by Richard Nice). Cambridge: Cambridge University Press.

Clamagirand, Brigitte

1975 La maison Ema (Timor Portugais). Asie du Sud-Est et Monde Insulindien $6(2-3): 35-60$.

Cunningham, Clark E.

1964 Order in the Atoni house. Bijdragen tot de Taal-, Land-en Volkenkunde 120:34-68.

Dall, G.

1982 The traditional Acehnese house. In J. Maxwell (ed.) The Malay-Islamic world of Sumatra: studies in politics and culture, pp.34-61. Melbourne: Monash University Centre of South-East Asian Studies.

Ellen, Roy

1986 Microcosm, macrocosm and the Nuaulu house: concerning the reductionist fallacy as applied to metaphorical levels. Bijdragen tot de Taal-, Landen Volkenkunde 142:2-30.

Endicott, Kirk

1970 An analysis of Malay magic. London: Cambridge University Press.

Errington, Shelley

1983 Embodied sumangé in Luwu. Journal of Asian Studies 42:545-570.

1984 The construction of gender in Southeast Asia: a call for papers. Unpublished paper.

Esterik, Penny van

1984 Continuities and transformations in Southeast Asian symbolism: a case study from Thailand. Bijdragen tot de Taal-, Land-en Volkenkunde 140:77-91.

Forth, Gregory L.

1981 Rindi: an ethnographic study of a traditional domain in eastern Sumba. The Hague: Nijhoff.

Fox, James J. (ed.)

1980 The flow of life: essays on eastern Indonesia. Cambridge, Mass.: Harvard University Press.

Guerreiro, Antonio 
1987 "Longue maison" et "grande maison": considérations sur l'ordre social dans le centre de Bornéo. In Charles Macdonald (ed.) De la hutte au palais: sociétiés "àmaison" en Asie du Sud-Est insulaire, pp.45-66. Paris: CNRS.

Hicks, David

1976 Tetum ghosts and kin: fieldwork in an Indonesian community. Palo Alto: Mayfield.

Hitchcock, Michael J.

1986 Basket makers of the highlands: the Dou Wawo of Bima, Sumbawa. Expedition 28(1):22-28.

Horridge, G.A.

1986 A summary of Indonesian canoe and Prahu ceremonies. Indonesia Circle 39:3-17.

Howe, L.E.A.

1983 An introduction to the cultural study of traditional Balinese architecture. Archipel 25:137-158.

Humphrey, Caroline

1988 No place like home in anthropology: the neglect of architecture. Anthropology Today 4(1):16-18.

Jaspar, M.

1964 From patriliny to matriliny: structural changes among the Redjong of southwest Sumatra. PhD thesis, The Australian National University, Canberra.

Kana, N.L.

1980 The order and significance of the Savunese house. In James J. Fox (ed.) The flow of life: essays on eastern Indonesia, pp.221-230. Cambridge, Mass.: Harvard University Press.

King, V.T.

1985 Symbolism and material culture: some footnotes for Penny van Esterik. Bijdragen tot de Taal-, Land-en Volkenkunde 141:142-147.

Kis-Jovak, J.

1980 Autochthone Architektur auf Siberut. Zürich: Eidgenössische Technische Hochschule.

La Fontaine, J.S.

1981 The domestication of the savage male. Man 16:333-349.

Lévi-Strauss, Claude 
1983 The way of the masks. London: Cape.

Lewis, E. Douglas

1983 Opposition, classification and social reproduction: gender as operator in Tana Ai thought. Working paper presented to the research seminar on Gender, Ideology and Social Reproduction, Canberra: Department of Anthropology, Research School of Pacific Studies, The Australian National University, August 1983.

Loeb, Edwin M.

1935 Sumatra: its history and people. Vienna: University of Vienna Institut für Völkerkunde.

MacCormack, Carol P. and Marilyn Strathern (eds)

1980 Nature, culture and gender. Cambridge: Cambridge University Press.

Macdonald, Charles (ed.)

1987 De la hutte au palais: sociétés "àmaison" en Asie du Sud-Est insulaire. Paris: CNRS.

McKinnon, S.

1983 Hierarchy, alliance and exchange in the Tanimbar islands. PhD thesis, University of Chicago.

Manguin, P.

1986 Shipshape societies: boat symbolism and political systems in insular Southeast Asia. In David G. Marr and A.C. Milner (eds) Southeast Asia in the 9th to 14th centuries, pp.187-213. Singapore and Canberra: Institute of Southeast Asian Studies, Research School of Pacific Studies, The Australian National University.

Oliver, Paul

1987 Dwellings: the house across the world. London: Phaidon.

Ortner, Sherry B.

1974 Is female to male as nature is to culture? In Michelle Zimbalist Rosaldo and Louise Lamphere (eds) Woman, culture and society, pp.67-88. Stanford: Stanford University Press.

Pelras, Christian

1975 La maison Bugis: formes, structures et fonctions. Asie du Sud-Est et Monde Insulindien 6(2-3):61-100.

Rassers, W.H.

1959 Pañji, the culture hero: a structural study of religion in Java. The Hague: Martinus Nijhoff. 
Schefold, Reimer

1982 The efficacious symbol. In P. Erik de Josselin de Jong and E. Schwimmer (eds) Symbolic anthropology in the Netherlands, pp.125-142. The Hague: Martinus Nijhoff.

Schulte Nordholt, H.G.

1971 The political system of the Atoni of Timor. The Hague: Martinus Nijhoff.

1980 The symbolic classification of the Atoni of Timor. In James J. Fox (ed.) The flow of life: essays on eastern Indonesia, pp.231-247. Cambridge, Mass.: Harvard University Press.

Sellato, Bernard

1987 Note préliminaire sur les sociétés “àmaison" àBornéo. In Charles Macdonald (ed.) De la hutte au palais: sociétés "àmaison" en Asie du Sud-Est insulaire, pp.15-44. Paris: CNRS.

Siegel, James T.

1969 The rope of God. Berkeley: University of California Press.

Snouck Hurgronje, C.

1906 The Acehnese (2 volumes). Leiden: E.J. Brill.

Strathern, Marilyn

1984 Domesticity and the denigration of women. In Denise O'Brien and Sharon W. Tiffany (eds) Rethinking women's roles: perspectives from the Pacific, pp.13-31. Berkeley: University of California Press.

Tiffany, Sharon W.

1978 Models and the social anthropology of women: a preliminary assessment. Man 13:34-51.

Tjahjono, Gunawan

1988 Center and duality in Javanese dwellings. Paper presented to International Symposium on Traditional Dwellings and Settlements in a Comparative Perspective, University of California, Berkeley, April 1988.

Waterson, Roxana

1990 The living house: an anthropology of architecture in South-East Asia. Kuala Lumpur: Oxford University Press.

Weiner, Annette B.

1978 The reproductive model in Trobriand society. Mankind 11:175-186.

Wessing, Robert 
Inside Austronesian Houses

1978 Cosmology and social behavior in a West Javanese settlement (Southeast Asia Series No. 47). Athens, Ohio: Ohio University Center for International Studies.

\section{Notes}

1 For analyses of some other examples of recurring symbolic themes and associations in Austronesia see Barnes (1977), Esterik (1984), King (1985), Horridge (1986) and Manguin (1986). 